\title{
Science and Technology in Elijah Muhammad's Nation of Islam
}

\author{
Astrophysical Disaster, Genetic \\ Engineering, UFOs, White Apocalypse, \\ and Black Resurrection
}

Edward E. Curtis IV

\begin{abstract}
This article explores the centrality of science and technology to religious thought and practice in Elijah Muhammad's Nation of Islam from the 1950s through the 1970s. Tracing the dynamic meanings of scientific knowledge in the context of the postwar United States, the article's central argument is that like other UFO and extraterrestrial religions, the Nation of Islam emphasized scientific, material, and empirical over spiritual and supernatural understandings of religion. It also suggests how members of this new religious movement studied and attempted to live according to the scientific and mathematical principles derived from their prophet's cosmological, ontological, and eschatological teachings on the nature of God, the origins and destiny of the black race, and the beginning and end of white supremacy.
\end{abstract}

KEYWORDS: Nation of Islam, UFOs, science and religion, Elijah Muhammad

Nova Religio: The Journal of Alternative and Emergent Religions, Volume 20, Issue 1, pages 5-31. ISSN 1092-6690 (print), 1541-8480. (electronic). (C) 2016 by The Regents of the University of California. All rights reserved. Please direct all requests for permission to photocopy or reproduce article content through the University of California Press's Reprints and Permissions web page, http://www.ucpress.edu/journals.php?p=reprints. DOI: $10.1525 / \mathrm{nr} .2016 .20 .1 .5$. 


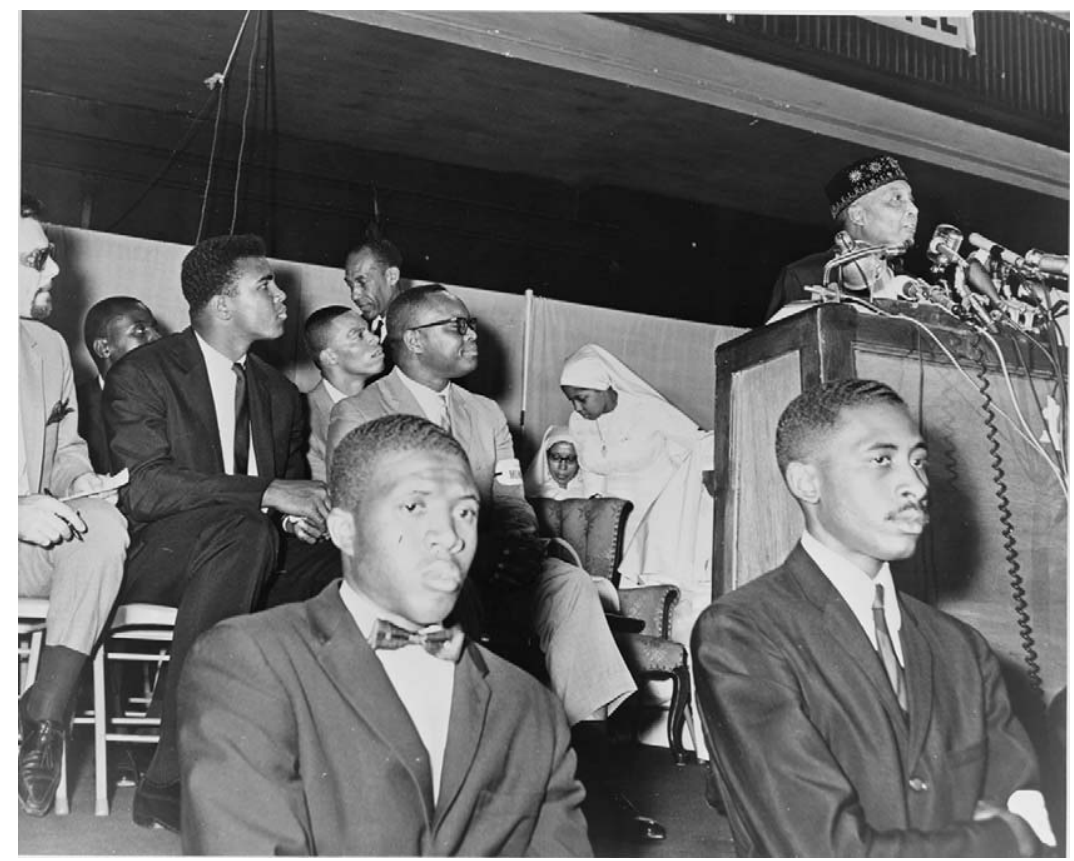

Figure 1. The Honorable Elijah Muhammad, also known as the Messenger of Allah, often touted Islam as a scientific way of life. In this 1964 address, boxer and follower Muhammad Ali listens intently. Stanley Wolfson, Photographer, Photo from Library of Congress.

$\mathrm{W}$ hile the Nation of Islam has received a lot of scholarly attention, few works have interpreted the scientific and technological elements of its religious thought and practice. ${ }^{1}$ Past studies of the Nation of Islam have focused on the group's black nationalist politics and its program of racial uplift, specifically, the movement's call for racial separation from the white-dominated public sphere; its gender dynamics; its organizational history; and its religious ethics, rituals, and doctrines, among other themes. ${ }^{2}$ This article shows how the movement's religious thought and practice also revolved around several interrelated claims involving science: (1) that Islam was the natural, scientific, and technologically-advanced religious heritage of black and Muslim people; (2) that human abuses of science and technology had resulted in a distorted human ontology, immorality, and an unjust social order; (3) that white supremacy would be ended though the intervention of a horrible and divine technology, specifically a UFO called the Mother Plane; and (4) that restoring black bodies and minds to their natural, scientific state was necessary to achieve long-lasting justice and equality.

Founded in 1930 by the mysterious W. D. Fard Muhammad in Detroit, Michigan, the Nation of Islam became the most popular 
American Muslim movement of the postwar era under the leadership of its prophet, Elijah Muhammad (1897-1975). ${ }^{3}$ Malcolm X (1925-1965), Muhammad's chief lieutenant in the 1950s and early 1960s, helped the movement grow into a national network of congregations with at least tens of thousands, perhaps over a hundred thousand members-and certainly many more sympathizers. ${ }^{4}$ By the early 1960s, the Nation of Islam also became the most prominent black nationalist alternative to the mainstream civil rights movement, as Martin Luther King, Jr. (1929-1968), indicated in his 1963 Letter from a Birmingham Jail..$^{5}$ Rather than presenting a static picture of the Nation of Islam from its founding in 1930 through its subsequent split in the late 1970s into two major groups-one led by Imam W. D. Mohammed (1933-2008) and the other led by Minister Louis Farrakhan (b. 1933) - this article limits its discussion of science and technology to the era when it had the greatest impact on United States history. As shown below, narrating the movement within an historical period that included moments such as the 1947 postwar UFO sightings, police and other state-sanctioned violence against African Americans in the 1950s and 1960s, public revelations in the 1960s about the extensive nature of state-sponsored eugenics programs, and the development of the birth control pill, approved for contraceptive use by the United States Food and Drug Administration in 1960, helps to contextualize the meaning of science and technology within the movement.

Since many mainstream scholars, the media, and the Federal Bureau Investigation constructed the postwar Nation of Islam as exotic, bizarre, and dangerous, many of its more unusual elements did not become the subject of serious academic investigation for decades. ${ }^{6}$ This is particularly true with regard to its scientific aspects. While the Nation of Islam's novel theories of the beginning of the world, the origins of the white and black races, and the end of the world might be considered mythological pseudo-science by mainstream scientists and casual observers alike, this article argues for an approach that takes these claims seriously by employing the insights of scholarly literature on new religious movements and especially extraterrestrial and UFO religions. Like other extraterrestrial and UFO religions, the Nation of Islam's teachings on theology, cosmogony, theodicy, and soteriology emphasized "the scientific, the material, and the empirical."7 As Benjamin Zeller has argued, "UFO religions demonstrate their scientific nature though offering materialistic explanations of what religions traditionally have understood as supernatural topics." They understand "all knowledge and knowable things as comprised of physical, tangible matter" and "treat knowledge as derived from the physical, tangible universe that human beings can access through their five senses."

Like other new religious movements, including extraterrestrial and UFO religions, the Nation of Islam also appealed to and reinterpreted some of the basic traditions of a major world religion in order to present 
what it considered a more authentic dispensation. ${ }^{9}$ The group appropriated the religious authority of the Qur'an (and just as much, the Bible), but reinterpreted these sacred texts in light of revelations delivered by its leader, Elijah Muhammad, who was identified as the Messenger of Allah-a title reserved by almost all other Muslims for the seventhcentury Arabian prophet, Muhammad ibn Abdallah (c. 570-632). As Paul Brian Thomas has argued about other extraterrestrial-inspired religious groups, the Nation of Islam offered a revisionist interpretation of canonical scriptures that unveiled what the group believed to be the previously hidden role of extra-terrestrials-in this case, god-like black scientists-in the origins of the world and its imminent demise. ${ }^{10}$ Thus, this study shows how in the Nation of Islam, it was not only scientific ideas that were important, but also scientists themselves. Relying on multiple primary sources, I demonstrate that the religious doctrines of the Nation of Islam portrayed some scientists as gods; using advanced knowledge and technology, scientists could create and destroy human beings and the worlds that they inhabit. ${ }^{11}$

Finally, this article outlines how the scientific ethos of the Nation of Islam was practiced inside the movement. To be sure, group members did not rely on repeatable, lab-based experiments to test their empirical and materialistic hypotheses, but Elijah Muhammad constantly beckoned them to use logic and their observations of both the natural world and their own bodies to verify his religious prophecies. Thousands of members of the Nation of Islam in the heyday of the movement from the 1950s to the 1970s intensely studied topics such as the separation of the Moon from the Earth, the genetic engineering of the white man, the distances between the sun and various planets in the solar system, and the impending end of the world via the appearance of the Mother Plane. Rather than singing to a mystery God, Elijah Muhammad preached, black people should study their true history and use that knowledge to become morally pure, physically healthy, politically independent, and economically selfsufficient. Such knowledge was indeed power. Understanding how astrophysical disaster and human abuses of nature resulted in a distorted human ontology, bad morals, and an unjust social order was a necessary step in strengthening and purifying black minds and bodies necessary to create racial justice and equality. Science had been responsible for the decline of black Muslim civilization, but it would also provide a means of restoring black Muslims to their natural state as rulers of the Earth.

\section{THE MATERIAL GOD, ASTROPHYSICAL DISASTER, AND BLACK SCIENCE}

Throughout the 1960s and 1970s, members of Elijah Muhammad's Nation of Islam located their attraction to Islam in contradistinction to 
Christianity partly in Islam's scientific and rational nature. To cite one typical example of an article written for Muhammad Speaks, the movement's weekly newspaper, Warner X Berry summarized that Allah "knows the natural laws that govern the universe. He knows the chemical and mathematical secrets to life." ${ }^{12}$ Dr. Leo X. McCallum, the group's most prominent dentist in the 1960s, similarly proclaimed that "there is nothing more scientifically, biologically, physiologically, or mathematically correct than Islam." Because Islam rejected the "basic dogmas of Christianity," he argued, it could appeal to the "rational" and "scientific man," including the growing number of professionals inside the movement. ${ }^{13}$ One man said that Elijah Muhammad's explanation of history and science did a far better job of dealing with the fossil record: while Christian [fundamentalist] preachers sometimes denied a far older timeline of the Earth, Islam, as taught by Elijah Muhammad, embraced it. ${ }^{14}$ As Sylane X put it in one 1964 article that rejected the un-scientific elements of Christianity: "I believe in no 'Holy Ghost' tales; no murderous Spanish Inquisition Catholic Church; no communion of saints, angels, spirits or spooks; no forgiveness of your people's sins against mine; no dry bones and decayed flesh resurrecting; and no life after physical death." 15 All of these beliefs for Sylane were irrational.

Member testimonies about Islam as a rational, scientific alternative to Christianity echoed the claims of movement leader Elijah Muhammad himself. In his 1965 magnum opus, Message to the Blackman in America, Elijah Muhammad frequently used appeals to rationality and materialism in explicating his theological, eschatological, and cosmological teachings. In his teachings on the nature of God, for example, the Messenger argued against the Christian doctrine of the Trinity (that God is both One and Three, or Father, Son, and Holy Spirit) by deeming it contrary to "nature and mathematics." Three cannot equal one, he stated. Moreover, Muhammad pointed out the logical inconsistency of the idea of an immaterial God spawning material beings: "They also teach that once upon a time He made the first man like Himself, in the image and likeness of Himself, but yet they believe that He, Himself, is not a man or human." Such teachings, preached the leader, were falsehoods created by the devil to "enslave the minds of the ignorant" so that the devil could enslave their bodies: "the American so-called Negroes are gravely deceived by their slave-masters' teaching of God and the true religion of God," he wrote. ${ }^{16}$ He reassured his "poor people": "Allah (God) loves us...fear not, you are no more forsaken." Muhammad advised them to "stop looking for a dead Jesus for help, but pray to Him whom Jesus prophesied would come after him." 17

Like other new religious movements, including UFO religions, the Nation of Islam claimed to reveal what Michael Barkun calls "stigmatized knowledge." 18 By offering new interpretations of old narratives, such groups, in the words of Paul Brian Thomas, "appropriate stigmatized and 
repressed knowledge as recovered truths while, at the same time, exposing those structures, institutions, and individuals implicit in the repression of knowledge." ${ }^{19}$ For instance, Elijah Muhammad cited Habakkuk, a book in the Hebrew Bible, as a text that actually revealed the material nature of God: "this prophet saw God as a material being belonging to the human family of the earth-and not to a spirit (ghost)." This material God was none other than W. D. Fard (pronounced Far-rad), who appeared in Detroit in 1930 for the purpose of teaching black people the truth about their identity and their role in cosmic history. ${ }^{20}$

While works such as the 1965 Message to the Blackman in America, which was a compilation of Elijah Muhammad's sermons and newspaper columns, made his teachings available to a wider audience, it was inside the Nation of Islam's many congregations (called both temples and mosques throughout this period) that rank-and-file believers studied such proclamations as part of their religious commitments. The religious education of Elijah Muhammad's Nation of Islam members and ministers included the requirement to learn and often memorize a number of anonymouslyauthored catechisms such as "The Rules of Islam," "Student Enrollment," "English Lesson C-1," "14 Questions," and "Actual Facts." Reflecting the idea that the truth about the origins of the universe and human beings had been hidden from black Americans, these sacred texts laid out many of the foundational beliefs and values of the movement. Like Elijah Muhammad's sermons and books, such texts couched theological, ethical-political, mythological, and aesthetic teachings as a truthful recollection of scientific fact. Rules and facts were presented as logical conclusions and observable data, even as they were interpreted at times in a mystical fashion. ${ }^{21}$

These catechisms oriented Nation of Islam believers in cosmic time and space. Spatial knowledge to be learned in "Actual Facts" included all planets in the solar system, their distances from the sun, their diameter, and the number of days it takes for each planet to rotate around the sun. Mercury, for example, was said, correctly, to be 36,000,000 miles from the sun, to take 88 days to rotate the sun, and to have a diameter of 3,000 miles. ${ }^{22}$ In addition, Nation of Islam members learned the weight of water and the speed of both sound and light. "Student Enrollment," another catechism to be mastered by members, included several facts about the Earth: "The square mileage of the Earth is 196,940,000 square miles. 57,255,000 square miles is land. $139,685,000$ square miles is water." 23

In these catechisms and other sacred texts, scientists are seen not merely as those who possess ultimate knowledge but also as people with the power to create and destroy planets and other cosmic entities. Elijah Muhammad himself was sometimes referred to as a "scientist." For example, his grandson, Jamil Muhammad, who was part of the movement's intelligentsia in the 1960s, argued that his grandfather "has the keys to 
every scientific field of life, to prove the Islamic principles of Allah's authority." 24 The Messenger proclaimed that it was a scientist, not any kind of spirit god, who set in motion the astrophysical disaster that eventually led to the fall of the black man. Tracing the presence of black people to the very origins of the universe 66 trillion years ago, he taught that "we were once called the moon people," as one version of "Actual Facts" states. "But Thanks to be Allah that we were not on the other part at the time of the separation 66 trillion years ago. At that time a scientist [emphasis in the original] wanted all the people to look alike, so he drilled a tube 3,000 miles in the Earth and filled it with high explosion and set it off." When this occurred, the water from the Moon, which was tipped over, poured into the Earth, which is why the Earth is " $3 / 4$ water," according to this modern scripture. ${ }^{25}$

The laws of modern physics and findings of modern astronomy aside, this teaching reveals how much human origins were understood in scientific terms, how scientists can change the history of the worlds, and how they do so by manipulating technology, in this case by drilling 3,000 miles into the Moon/Earth (which would be about three-quarters of the distance to the current planet's core). In Message to the Blackman, the scientist who separated the Earth from the Moon was identified as "God," and this particular scientist/god "wanted the [Moon] people to speak one language, one dialect for all, but was unable to bring this about," declared the Messenger. "He decided to kill us by destroying our planet, but still He failed." 26

The Earth's history was but a small moment in cosmic time, according to Elijah Muhammad. Much of the confusion among black people about their true history as makers of the universe comes from the Bible, he said. Consonant with many modern Christian fundamentalist readings of the Bible, Muhammad taught that the current era of history was 6,000 years long. To understand all of human history as only 6,000 years long, however, was to accept a bamboozling version of reality. "As I see it," he argued in his 1957 pamphlet, The Supreme Wisdom, "the Bible is very questionable." If you read the Bible literally, Muhammad said, it made no sense. For example, he pointed out, Genesis 1:1 declares that "the earth was without form and void; darkness was upon the deep and the spirit of God moved upon the waters." But if the Earth was without form, then what, he demanded to know, acted to contain the water: "what was the water on?" He also argued that "the Bible opens with the words of someone other than God trying to represent God and His creation to us." The writer of Genesis, he says, makes it seem as if God created the "heaven and the earth" in 4,004 B.C. and then created the first human being. But in light of W. D. Fard's teachings, Elijah Muhammad explained, "we know, now, that it refers to the making of the white race, and not the Heaven and the earth," which were made much earlier. He reassured his followers that there is "plenty of truth" in the Bible, and that prophets such as 
Moses "do not lie" but that it needs to be interpreted. The Bible was not as "as holy" as black people generally think, according to the Messenger, and if read without his guidance, it would be "the graveyard of my poor people (the so-called Negroes)." 27

Like the leaders of other extraterrestrial and UFO religions, Elijah Muhammad revised "biblical accounts of the origin of humanity into a narrative that includes contact, observance by, or interference on the part of alien intelligences." 28 The history of the original, black man dates not to 6,000 years ago, Elijah Muhammad preached, but to trillions of years ago. "We make .. . history every 25,000 years," he said. And "when such history is written," Muhammad wrote, "it is done by twenty-four of our scientists." In this much more expansive narrative of origins, scientists are the universal movers and shakers. These scientists not only have the ability to describe what has happened in the past but can also predict what will happen in the future and make it come to pass. One of the twenty-four scientists, Muhammad explained, "acts as Judge or God for the others." Once again, we see the word "God" being redefined to signify not some sort of spirit but instead a real man. "Twenty-three [scientists]," he continued, "actually do the work of getting up the future of the nation." 29 The phrase-"getting up"-can mean to acquire knowledge of or to cause something to happen. In this case, it may mean both.

One of the keys to understanding Nation of Islam science-and thus to knowledge of self and one's place in the universe-is noticing how important moments in time, measurements, and other numeric values either mirror one another or can be added to or subtracted from one another in order to reveal another important date, measurement, or figure. In teaching about the twenty-four scientists, for example, Muhammad notes that "there is a significance to the number 24." It parallels or is "in accordance" with "the hours in a day." 30 The number 24-and numbers more generally-did not signify some esoteric, abstruse meaning. Instead, the meaning was largely exoteric, revealing mathematical parallels that exist throughout time and space. Numeric values in the Nation of Islam were to be understood literally rather than figuratively. In most cases, numbers had to be interpreted in light of Elijah Muhammad's revelations, but they did not possess any sort of meaning that does not refer to some part of the natural, material world. Indeed, interpreting numbers in a non-scientific, immaterial manner would have done the work of the hoodwinking devil, distracting black people from real knowledge. The catechisms and teachings of the Nation of Islam combined modern scientific data from astronomy and geography with Elijah Muhammad's revelations to render a portrait of the universe that was knowable and ultimately changeable.

The understanding of mathematical and numerological likenesses in literal, material terms reveals a difference between the Nation of Islam and some other new religious movements that Catherine Albanese, 
following J. Stillson Judah, has labeled metaphysical religion. According to Albanese, one of the main components of American metaphysical groups is the idea that "material world is organically linked to a spiritual one."31 But in Elijah Muhammad's worldview, there was no spiritual world. The material world was all that was, is, and ever will be. From an emic (insider's) perspective, in the Nation of Islam there was no such thing as metaphysics-only physics. If Elijah Muhammad's Nation of Islam resembled any esoteric or metaphysical group, perhaps it came closest to its Masonic cousins from the Revolutionary era of United States history. As Albanese puts it, these more democratically-minded Freemasons "made an intellectual move that would later help to lift metaphysics, for many, out of its magical past and into a more rationalized future. Here the esoteric became exoteric. . . Masonry, literally, let the sun shine into the occluded secret of the Hermetic past." 32 In a similar way, the so-called secret of the black man's past, the truth, was available to all in Elijah Muhammad's Nation of Islam-men and women, middle-class and poor, ex-convicts and ex-addicts-if one was willing to become a disciplined student of the Messenger. In unveiling the "secrets" of Islam, talking about them to the general public, and publishing books that anyone could read, Elijah Muhammad showed that while the Nation of Islam may have been born in a 1930s religious milieu suffused with Masonic ideas, Rosicrucianism, New Thought, Theosophy, Spiritualism, black orientalism, and occult practices, it became a different kind of movement in postwar America. ${ }^{33}$ The Nation of Islam may have adopted various ideas from the Moorish Science Temple, which exemplified the lively esoteric scene that obtained in the interwar period, but by the late 1950s, if not before, it sought to de-mystify religion and convert all black people to a rational, scientific way of life, not establish a secretive cult in which only a select few possessed the power to liberate themselves from white supremacy. This is not to say that believers themselves did not sometimes interpret or experience Elijah Muhammad's Supreme Wisdom as form of gnosisadding their own spiritual and metaphysical understandings to his teachings-but for many movement members, as already seen above, it was precisely the rational, material style of thought that attracted them to Elijah Muhammad's movement in the first place.

\section{SCIENTIFIC REBELLION, GENETIC MUTATION, AND THE FALL OF BLACK CIVILIZATION}

In order to liberate themselves from white supremacy, said Elijah Muhammad, black people would have to learn how they had become second-class citizens. This narrative of Earthly origins was another example of Barkun's "stigmatized knowledge," a truth that had been repressed 
by the powerful and forgotten by the oppressed. Muhammad taught that after the Earth separated from the Moon, black people established human civilization in the Arabian city of Mecca. There were no white people then. The very first question that potential Nation of Islam members were asked to learn in "Student Enrollment" was: "Who is the original man?" The answer: "The Asiatic Black Man, Owner, Maker, cream of the planet Earth, God of the Universe and Father of Civilization."34 Noble Drew Ali (1886-1929), founder of the Moorish Science Temple of America, first popularized the idea that black people are Asiatic (or Asian, in contemporary parlance) in his 1927 Holy Koran of the Moorish Science Temple. Inspired by anti-colonial voices from the African Times and Orient Review, edited by Mohammed Dusé Ali (1866-1945), and the United Negro Improvement Association (UNIA) and its newspaper, Negro World, Ali taught that all non-European people were by nature Muslim, and further, that they were racially Asian, not black, Negro, or colored. ${ }^{35}$ The Nation of Islam adapted that teaching and then provided an elaborate historical explanation of the history of this Asiatic black Muslim man.

At the beginning of human civilization, black/Muslim men and women spoke Arabic, lived productive economic lives, and followed Victorian-like moral codes. As one section of the catechism, "14 Questions," proclaims, "The root of civilization is in Arabia at the Holy City Mecca, which means where wisdom and knowledge of the original man first started." 36 Not all scientists were happy in this paradise, however. One of them-unnamed by Elijah Muhammad and only called "dissatisfied"- "wanted to make all of us tough and hard in order to endure the life of the jungles of East Asia (Africa) and to overcome the beasts there." Relying on a common trope in American and African American culture, Africa was seen as the "jungle", as untamed nature, juxtaposed with the civilized world, which was represented in this narrative by "Mecca." In order to make black/Muslim people tough, this scientist made them have "kinky hair," according to Elijah Muhammad. ${ }^{37}$ Elijah Muhammad thus associated kinky hair with the toughness of nature, and though it was not a punishment, this kinky hair was seen by Muhammad as a natural impediment to middle-class respectability if it was not properly groomed. ${ }^{38}$

The creation of kinky hair in the jungles of Africa was nothing, however, compared to the genetic engineering undertaken by the mad scientist Yakub, the Arabic name for the biblical and Qur'anic Jacob. For C. Eric Lincoln, the story of Yakub was "the central myth of the Black Muslim movement."39 This black God/scientist hatched a plan that resulted in the making of the white man, a genetically inferior monster, a rapacious brute, a devil. According to the account in Elijah Muhammad's Message to the Blackman, which outlines the story of Yakub in far greater detail than any of the movement's catechisms, the Council 
of Scientists had written his role into history long before he was born. From the time when he was six years old, as he played with steel and sought to figure out the laws of magnetism, he told his uncle, "when I get to be an old man, I am going to make a people who shall rule you." His intelligence was out-sized-Yakub was called the "big head scientist" and he learned everything that Mecca's universities had to teach by the age of eighteen. Dissenters and troublemakers in Mecca began to follow him, tricked by his lies but also attracted to "promises of luxury," particularly the idea that slaves would relieve them of the burdens of labor. The Meccan authorities arrested him and sent him and his 6,000 followers into exile on Pelan, or the Mediterranean island of Patmos where the book of Revelation was revealed. ${ }^{40}$

Once there, Yakub made the white man through a multigenerational and murderous program of eugenics. When still in Mecca, according to Elijah Muhammad, Yakub had studied the "germ of the black man under the microscope" and had seen that there were two people inside of him, one black, one brown. His goal became to "separate the one from the other" in order to "graft the brown germ into its last stage, which would be white." As leader of his exiled community on Pelan, Yakub recruited "doctors, ministers, nurses and a cremator" to help him his carry out his plan, even after he died. In this dystopia, physicians were to perform blood tests on all potential heterosexual couples to identify the black and brown genes of the bride and groom. If the genes were all black, the minister would refuse to marry them on penalty of death. If a black child happened to be born on Pelan anyway, Yakub "ordered the nurses to kill all black babies ... by pricking the brains with a sharp needle as soon as the black child's head is out of the mother." And if the mother was watching, then the nurse was to lie to the mother and claim that the baby was an "angel child" that must be taken to heaven. The child would then be fed to "wild beasts," or if none was available, "Yakub told the nurses to give it to the cremator to burn." 41

Yakub's final solution for the black race reflected some of the most horrific applications of science and technology in the twentieth century. If the invocation of the crematorium was not a direct reference to Auschwitz-suggesting that such a teaching may have appeared after World War II-then at the very least its interpretation would have resonated as such in the postwar United States. This reference also implied the parallels between German rassenhygiene (racial hygiene) and racist eugenics programs in the United States. ${ }^{42}$ Though the scientific racism underpinning eugenics had been thoroughly undermined by the 1960s, thousands, perhaps tens of thousands of poor black women were still sterilized without their consent, at state-regulated public healthcare facilities as late as the 1970 s. $^{43}$ Elijah Muhammad pointed to a clinic at Fauquier County, Virginia, as only one site where such sterilizations were being performed in the 1960 s. "Sterilization is not birth control," he told 
his followers, "but the end of all possibility to bear children." Muhammad also saw birth control as an attempt to reduce the black population: "I say beware of being trapped into the kind of disgraceful birth control laws now aimed almost exclusively at poor, helpless black peoples who have no one to rely on." 44 These sterilizations were performed in a country where black bodies more generally constantly faced the threat of violence throughout the 1960s. Unprosecuted rapes of black women, the cruel beating of civil rights protesters, police violence toward black men, and the disproportionate losses of black soldiers in the Vietnam War verified for many African Americans that the United States was a racist society that seemed either not to care or even to take delight in violating black bodies. Elijah Muhammad's claim that white man was the devil, sometimes interpreted literally and at other times read metaphorically, made sense to many black people in this period. ${ }^{45}$

According to Elijah Muhammad, the white devils were destined to rule for a period of time. Living in the caves of Europe, uncivilized and violent white men eventually conquered black Muslim civilization and enslaved the noble black Tribe of Shabazz. Moses and Jesus all tried to civilize the white man, and Muhammad of Arabia attempted to convert whites to Islam, but their efforts came to naught. Black/Muslim people forgot their original language (Arabic), their names (such as Shabazz), their religious identity (Islam), their strong middle-class morals, and their rights of political self-determination. They no longer knew themselves; they took on the unnatural religion of their slave masters, Christianity; and they sought to integrate into the corrupted and racist society of the white man. In short, they became the victims of cultural, political, religious, and economic imperialism. Weak and ignorant, Muhammad said, they were brought on a slave ship to what was called the untamed wilderness of North America, a place that lacked civilization, where they ate all manner of unhealthy food, began to drink liquor, and engaged in fornication and other sinful behavior. ${ }^{46}$

But the Nation of Islam and its prophet, Elijah Muhammad, reassured the believers that the period of white supremacy would come to an end. Relying on basic arithmetic, "Actual Facts" taught that devil's rule began its decline in 1914, a year also said by the Jehovah's Witnesses to signal the end of the world. ${ }^{47}$ As detailed in Message to the Blackman in America and many other sources, Elijah Muhammad explained that God then appeared in the flesh. In 1930, W. D. Fard Muhammad, or Allah, arrived in Detroit. He created the Temple of Islam. Fard was, above all, a teacher, not a magician. According to Elijah Muhammad, "he began teaching us knowledge of ourselves, of God and the devil, of the measurement of the earth, of other planets, and of the civilization of some of the planets other than earth." Once again, he framed knowledge not only in theological but also in scientific terms: "He measured and weighed the 
earth and its water; the history of the moon; the history of the two nations, black and white, that dominate the earth." 48

By 1934, W. D. Fard, Allah, had left Detroit, and a power struggle ensued among his followers. Elijah Muhammad also fled Detroit in the wake of Fard's departure. After a period of itinerancy, he established his headquarters in Chicago at the Nation of Islam's Temple No. 2. From 1943 to 1946, Muhammad served a prison sentence for a federal conviction on draft evasion charges. He emerged in the late 1940s as the undisputed leader of what was quickly becoming a national movement. Aided in the 1950 s by the charismatic speaker and effective organizer Malcolm X, the Nation of Islam attracted national press attention when CBS television reporter Mike Wallace (1918-2012) and journalist Louis Lomax (1922-1970) produced a documentary on the group entitled The Hate that Hate Produced (1959). ${ }^{49}$ This was when Elijah Muhammad's teaching about the white devil and his imminent demise became a foil for the civil rights movement, which could depict the Nation of Islam as the unfortunate byproduct of bad race relations.

\section{BLACK RESURRECTION, THE MOTHER PLANE, AND WHITE APOCALYPSE}

Despite the fact that law enforcement, the press, and civil rights leaders increasingly understood the Nation of Islam as a radical movement, the group did not advocate political revolution or violent social change. Instead, Elijah Muhammad ordered his believers to avoid mainstream electoral politics, obey federal and state laws (which included the right of self-defense), and focus their efforts on personal moral reform, family-building, petit-bourgeois economic activity, and the institutional growth of the Nation of Islam. ${ }^{50}$ Because there was no afterlife, no heaven to which the immaterial soul would travel after death, Elijah Muhammad beckoned his followers to live the good life in the present. Reinterpreting both Christian theology and a widely shared belief among practitioners of metaphysical religions, Elijah Muhammad taught that heaven and hell were not different realms of existence or states of mind, but rather were characterized by the conditions of one's physical, material existence on Earth: "He (Allah) has made it clear what constitutes heaven on earth: Freedom, Justice, Equality; money, good homes and friendship in all walks of life." 51 The Messenger had been sent, he said, to mentally resurrect the dead, teach them knowledge of self, and provide them with a path toward paradise. His job was to heal the mind and the body, and restore to its original, natural, and civilized state.

This resurrection was already happening, according to the hundreds of Nation of Islam members who published their stories with Muhammad Speaks newspaper, in meetings at local congregations, and in personal 
testimonials that were shared door-to-door and on busy street intersections in African American neighborhoods. Evidence for the change could be found in the personal behavior of members. Following a regime of moral norms that recalled the middle-class respectability of turn-ofthe-century African American churches, members sought to observe sexual abstinence before marriage, dress in a dignified fashion, always be on time, seek gainful employment, and use proper etiquette. Under the aegis of the male and female auxiliaries of the movement-respectively, the Fruit of Islam and Muslim Girls Training-heterosexual monogamy was also strictly enforced (except for the prophet himself). Special emphasis was placed on disciplining, purifying, protecting, and strengthening the black body. ${ }^{52}$

One of the most important aspects of communal life in the Nation of Islam during this era was the production and consumption of healthy food. Believers were told to avoid red meat, white flour, and foods with additives. Alcohol, tobacco, shellfish, the "filthy" pig, and a number of foods associated with Southern slave culture, which Elijah Muhammad considered to be undignified and uncivilized, were banned. Many "soul food" staples-from cornbread and collard greens to black-eyed peas and catfish-were unwelcome in the Nation of Islam. ${ }^{53}$

These discourses on the ethics of food, like so many aspects of the Nation of Islam's religious thought and practice, were framed in scientific, mathematical terms. Take, for example, the commandment to limit caloric intake. Concerned about obesity and diabetes among African Americans, the Messenger taught his followers to eat one meal per day. According to Muhammad, Allah "taught us that the slave-masters had taught us to eat the wrong food and this wrong food is the cause of our sickness and short plan of life. He declared that he would heal us and set us in heaven at once." 54 If they ate once daily, he promised, they would live much longer lives, just like people in the Bible. In the section of the "Actual Facts" catechism entitled "How to eat and live" (which by the 1970s would be adapted as the title of a two-volume dietary guide published by Elijah Muhammad), believers were to memorize the following formulae. The left column represents how often one should eat; the right column represents how long one would live if one ate at that frequency:

$$
\begin{aligned}
& 24 \text { hours ... . } 150 \text { years } \\
& 48 \text { hours ... } 300 \text { years } \\
& 72 \text { hours ... } 450 \text { years } \\
& 4 \text { days ... . 600 years } \\
& 7 \text { days ... . 1,050 years }
\end{aligned}
$$

Methuselah lived to be 960 years old, and ate once every seven days. ${ }^{55}$

The idea that Methuselah lived to be 960 years old because he ate only once every seven days is obviously problematic-at that rate, he might have died from malnutrition. But what this graph communicates 
is that eating less frequently could extend one's lifespan, and further, that the frequency of eating and one's lifespan could be understood as a simple equation. Many male and female members were very successful in limiting their meals to once daily, and dozens of them testified that this practice had cured them of various illnesses and made them feel much healthier. ${ }^{56}$ Samuel $25 \mathrm{X}$ wrote that these teachings made good scientific sense. His article, "Recent Scientific Research Confirms Messenger's 40-Year Dietary Teaching," offered data and conclusions from the American Journal of Public Health as proof. ${ }^{57}$

Clean living made it possible for members of the Nation of Islam not only to live in heaven right now, but also to prepare for the coming apocalypse. The urgency of living according to Elijah Muhammad's interpretation of Islam stemmed from both the promise of a better life and protection from imminent doom that Elijah Muhammad and many of his followers believed would befall the world. Once again framing the story of the original people in cosmic time-past, present, and futureSister Kris X of Temple/Mosque No. 7 in Harlem, New York, asked all black/Muslim people to join her in the "Holy City":

In the Holy City

Where the Righteous doth abode.

To ever hear the name Allah and walk in silken robes.

$\mathrm{Oh}$, to sail the streets of justice,

Allah's breath the guiding wind.

Your ship is safely anchored;

Bow and Stern are free from sin....

Belief in Allah and His Messenger

Reserves the seat and pays the fare.

Hurry! Quick! Take flight

Lest ye be left behind. The hour glass of judgment

Has always been on time.

The trial is almost over;

Harvest time is nigh.

The tried have shed their grave clothes;

There's no heaven in the sky. ${ }^{58}$

The lives of black/Muslim people, waxed Sister Kris, could be as glorious as those of their ancestors in the mythical Mecca before the genetic engineering of the white man. If black/Muslim people recommitted themselves to Islam, then they could be saved.

If they did not, then, like the white man, they faced annihilation from the coming apocalypse, which would be effected by the horrible Mother Plane. "Nothing of the present world of mankind would be left," Elijah Muhammad promised. This vehicle of global destruction would be a UFO that would appear in the sky one day. According to Elijah Muhammad, W. D. Fard "pointed out a destructive dreadful-looking plane that is made like a wheel in the sky today. It is a half-mile by half-mile square; it is 
a humanly built planet." Perhaps inspired by the many spirituals about Ezekiel's wheel that he had heard as a child growing up in Georgia, Muhammad said that the biblical prophet Ezekiel had seen this UFO long ago. ${ }^{59}$ Ezekiel, like W. D. Fard, had warned people about what was coming: "Allah has warned us of how He would (one day) destroy the world with bombs, poison gas, and finally fire that would consume and destroy everything in the present world."60

The idea that this UFO was feminine-a mother-mirrors the ways that femininity was constructed elsewhere in Elijah Muhammad's Nation of Islam. ${ }^{61}$ As seen in the discussion of family planning and eugenics above, mothers had the power in movement religious thought to destroy and create life. The Mother Plane would destroy the old order in order to restore the reign of black/Muslim civilization. "There is no known equal of the Mother Plane," Elijah Muhammad declared. But he also warned not to worship the Mother Plane itself: "Do not marvel at the make of this plane," because "it is God Who made the universe." The mother plane is "dreadful" but "her work is a display of the power of the mightiest God." The proper reaction to the mother's awesome power, according to the Messenger, was not to worship her but to "seek refuge in Allah (God) from the destructive work to come from the Mother of planes." 62

Notwithstanding Elijah Muhammad's claims that Fard had taught him about the Mother Plane during the early 1930s, many of its elements have a postwar flavor. Though American popular culture contained numerous references to aliens and spaceships by the early 1930s, it was not until 1938 until Orson Welles (1915-1985) and Howard E. Koch (1901-1995) adapted H. G. Wells' novel, War of the Worlds (1898), for a nationally broadcast CBS radio show. Millions tuned in to listen, and panic ensued as some listeners really believed that Martian spaceships were attacking Earth. ${ }^{63}$ Most Americans did not yet picture these spaceships as round flying disks - that is, as wheels in the sky, like the Mother Plane. According to a poll by the Gallup organization, this was still the case during much of the 1940s. But by 1947, pilot Kenneth Arnold of Boise, Idaho, saw "nine shiny disks ... flipping and flashing along over Mount Rainer," and soon, people across the continental United States, including United States Air Force Lt. Joseph C. McHenry, were seeing spherical UFOs everywhere. ${ }^{64}$ One of the more significant UFO sightings that year was by William Brazel, who found the remains of a weather balloon in Roswell, New Mexico, inspiring decades of conspiracy theories about the United States government's role in covering up the presence of extraterrestrial visitors. By 1950, when Frank Scully published his bestseller, Behind the Flying Saucer, the association of a UFO with a flying saucer became ubiquitous, even automatic. ${ }^{65}$ The Roswell myth, as it would be called, helped to spawn not only movies such as the 1956 Earth vs. the Flying Saucer, but also various new religious movements, including the Chicago-based 
"Seekers," who believed that the world would be destroyed in 1954 by a flood but that true believers would be saved by a flying saucer and transported to a heavenly planet. ${ }^{66}$ The similarities between popular postwar beliefs about UFOs and the Mother Plane myth-not to mention the Chicago location of the Seekers group-at the very least suggest that there was a fertile context in which Elijah Muhammad's teachings would be embraced and valued.

By the late 1960s and early 1970s, Elijah Muhammad revealed further details about the Mother Plane. These teachings were compiled in a 1973 book entitled The Fall of America. In this 257-page work, the Mother Plane was explained as the coup de grâce in the destruction of the white-dominated world that began 6,000 years ago. According to the Messenger, signs of the apocalypse in the early 1970s included natural disasters, the nagging presence of war, the sexual revolution, and the decline of the dollar (whose convertibility to gold was temporarily suspended by President Richard Nixon in 1971 and later taken off the gold standard permanently) ${ }^{67}$ Elijah Muhammad was only one of many American doomsayers, most of whom were Christian millennialists, to read these particular phenomena as signs of the eschaton during this period. ${ }^{68}$

But the Messenger's reading of how and why a UFO would destroy the white supremacist dispensation was unique. Relying on the King James Bible, the Qur'an, and W. D. Fard as sources, Elijah Muhammad explained the nature of this technological wonder. First, he said, black/Muslim scientists were in control of the Mother Plane, and they "know what you are thinking before the thought materializes." 69 According to Elijah Muhammad, this is what the Qur'an 50:16 meant when God says, "and We certainly created man, and We know what his mind suggests to him-and We are nearer to him than his life-vein." 70 Because these scientists/gods are omniscient, they could see what is coming before it happens. Government scientists might try to destroy the Mother Plane by sending fighter jets against it, "but if a plane did get close enough ... it would be destroyed instead."71 The Mother Plane also had the capacity to lift whole mountains from their moorings, defy Earth's gravity for one year, and generate its own oxygen and hydrogen.

Exactly how would the Mother Plane destroy the present order? Quoting from the book of Ezekiel, Muhammad noted that the Mother Plane was shaped like a wheel, that there were "four living creatures" inside of it, and that "their word was as it were a wheel in the middle of the wheel" (Ezekiel 1:16). These creatures will scatter "coals of fire" over cities, which could mean, according to the Messenger, that fire or bombs would be released. The bombs "would automatically be timed to burrow quickly to a position of one mile below the surface of the earth where they are timed to explode."72 These bombs, however, would not act like normal explosives. Instead, they would "separate from the righteous that 
which is hindering the righteous from making progress and... destroy the effect of the poison of that which has opposed the righteous." Elijah Muhammad provides little explanation of how exactly this will work. The source of the black/Muslim man's poison-presumably the devilwould be completely destroyed. He compared the event to "being bitten by a rattlesnake. Quickly medication is administered in order to minimize the effect of the poison upon flesh and blood until a complete cure is effected; and the patient recuperates and is well again." White people and black people who were disbelievers in Islam might never recover from the bite. They would live in a state of hell because they refused to believe in the truth. Those willing to "take their medicine" via the harsh technology of the Mother Plane would, however, be cured, their bodies purified of white poison. ${ }^{73}$

In 1972, just three years before his death, Elijah Muhammad revealed a bombshell interpretation of the Mother Plane myth: the white apocalypse would not actually kill all white people. "Now, I must tell you the truth," he explained in an interview, "there will be no such thing as elimination of all white people from the Earth.... No, because there are some white people today who have faith in Allah and Islam though they are white, and their faith is given credit." 74 What faith was this, exactly? The Messenger did not expound on the comment, and there was little indication of how such faith could possibly transform the white man whose very genetic composition made him devilish. That such a transformation was possible, however, had been hinted at even before the 1970s. In 1957, Muhammad wrote in the Supreme Wisdom that Caucasian people "just haven't the nature to do good unless they are returned into that which they were taken from." 75 Though there was also no further comment in 1957 on how the uncivilized, brutish, violent, and unjust nature of the white man could be changed, the idea that they would be restored to "that which they were taken from" seems to indicate that they or their genes could be altered to reflect the inherently good and divine nature of the original black man. Then, in 1967, at the annual Saviour's Day Convention in Chicago celebrating W. D. Fard, Muhammad revealed that evil一whiteness-was inherent even to the original, black man. "White was in the Black," he told the crowd, "but no one had ever made an attempt to bring it out." In his scientific experiments, Yakub-like Jacob of the Hebrew Bible-was "wrestling the white man out of the black man." 76

In the post-apocalyptic world, humankind would be purified of this evil whiteness. The original man would reign, just as he was meant to be. The white part of humanity-the part responsible for colonialism, imperialism, slavery, genocide, the Holocaust, world wars, and the threat of nuclear annihilation-would be gone. "Peace, joy, and happiness will have no end," the Messenger promised in The Supreme Wisdom. "Wars will be forgotten.... It will be the heaven of the righteous forever; no sickness, 
no hospitals, no insane asylums, no gambling, and no cursing or swearing....All fear, grief and sorrow will stop."77 The promise of the white apocalypse assured people of color that their cries for justice would eventually be heard; for some, the white apocalypse would be righteous revenge. But the end of the white supremacy was supposed to be a means to an end, a better world in which sinful behavior of whites-but not all white people-would be destroyed. The vision expressed an innocent belief in humanity's true nature as good and generous. It was also a terrible vision of racial genocide. But unlike technologies of white supremacy, it was not used to justify violence toward the Other; it was used to reassure the oppressed that their day was coming and in the meantime they better get busy not with attacks against white people but with reform of themselves, their families, and their local communities.

Beyond the way that the Mother Plane would be the vehicle, or means, through which this new order would be established, it is also important to understand how the technology itself was a form of revelation. As its most perceptive interpreter has pointed out, Elijah Muhammad's doctrine of the Mother Plane reflects larger modern orientations toward technology as a form of religious revelation, especially with regard to the technologies of destruction such as those in the prophecies of Ezekiel. In his book, Children of Ezekiel, Michael Lieb explains how Ezekiel's vision of the apocalypse used the technological marvel of the merkaba, the throne-chariot, to transform the theoretical vision of the end of the world into a concrete thing, a "new order." Riffing on Martin Heidegger's discourses on technology, Lieb argues that in the modern age, "technology is not the result of that which is simply 'produced' through the act of causing something to be formed or constructed; rather it is that though which the being of a thing is 'manifested' or 'disclosed." 78 In its essence, technology is a poetry of unconcealment, revealing something that already exists. While some commentators on Ezekiel see his visions as a form of madness or pathology, Lieb points out how Jewish mystics have often regarded Ezekiel's vision as "a source of triumph of matter over spirit." What matters in Ezekiel's elaborate vision of the wheel was not the power or idea behind its creation, but the wheel itself. This interpretation of Ezekiel's wheel anticipated the way that UFO religions and other new religious movements similarly regarded technology not only as a vehicle of revelation, but as a form of revelation itself. ${ }^{79}$ The thing - the technology-is what counted. As we have seen, public scientific discourse in the Nation of Islam during the 1950s and 1960s included symbolic elements, but in general, the catechisms and other sacred texts of Elijah Muhammad's Nation of Islam overwhelmingly framed religion in the vocabulary of material reality and observable truth.

This was the case even as Elijah Muhammad began to talk publicly about his telepathic abilities and the once repressed truth that ordinary people could develop parapsychological powers. In 1972, Elijah 
Muhammad made a series of speeches (now available on the Internet) ${ }^{80}$, later compiled in a posthumous book entitled The Theology of Time, that were framed as what might be called esoteric wisdom. In a lecture entitled "The Veil Must Be Lifted," Muhammad explained to his listeners that "what you have been told [before] was not told to you for you to understand. It was not given to you to understand before this time." Now, he said, he would reveal the "secrets of all truth that have put in a symbolic manner. Now, today, the veil must be lifted and you must understand." 81 This striking assertion signaled a shift toward the deployment of more explicitly metaphorical language in the Nation of Islam, though the wisdom to be gained was once again of a material reality, not some heavenly, metaphysical sphere.

Elijah Muhammad declared that he could hear the scientists who rode in the Mother Plane and told his followers that they, too, could develop the power of telepathy. One could read the minds of others, he preached, "if you will take time, clear your mind, and then go into some place where no one will disturb you." This power applied either to what was happening on the Wheel-the Mother Plane-or simply another person. "After a while you can hear what the Brother is saying to himself. Maybe you can hear the motors going in one of the Wheels." 82 Others had done it before them, including Jesus, who was described as another scientist who possessed a "radio in the head," that is, an ability to "tune in" the thoughts of other people. Elijah Muhammad's comment paralleled many of the esoteric understandings of Jesus popular in the interwar period, beliefs that had been expressed in Noble Drew Ali's 1927 Holy Koran of the Moorish Science Temple. But once again showing his distance from more typically metaphysical religion, Muhammad's parapsychology did not reveal the existence of some immaterial, spiritual realm of existence; it established the presence of real, physical realities that could be understood using the human senses. As Elijah Muhammad appropriated more parapsychological language in discussing the nature of the human mind, he continued to couch his teachings in technological and physicalist terms. Once a believer had eliminated unnecessary noise and was in a quiet place, Elijah Muhammad promised, the believer would be able to hear the "motors" of the Mother Ship and listen to the "radio in the head." This would result in further scientific evidence to support the existence of the Mother Plane and its important mission.

\section{CONCLUSION}

In 1975, the Honorable Elijah Muhammad died, and his son, W. D. Mohammed, also known as Warith Deen Muhammad, emerged as the leader of the Nation of Islam. Imam Mohammed, as he became known, 
implemented what he called the "Second Resurrection," reinterpreting various aspects of the Nation of Islam's teachings in accordance with the Sunni Islamic pillars of both belief and practice. Believers were taught that Master Fard was not actually God and that his father, Elijah Muhammad, was not the final Messenger of God. The myth of Yakub's genetic engineering was replaced with a more standard Sunni narrative of how God created humankind-of one race-from a blood clot (Qur'an, Sura al-'Alaq, 96:1). Believers were asked to fast during the lunar month of Ramadan, not in December; to go on hajj to Mecca, if possible; and to perform salat, the prescribed prayers involving a series of prostrations, five times a day. The world would come to an end during the Day of Judgment, and it would be an awful day, but the Mother Plane would not be the technology of God's destructive agency. The new Nation of Islam still emphasized traditional themes of black pride, a healthy diet, sexual modesty, and economic self-determination, but W. D. Mohammed saw the Qur'an and the Sunna, or Tradition of the Prophet Muhammad, as the sacred sources of authority that underwrote such practices. Mohammed also changed the name of the organization to the World Community of al-Islam in the West and then to the American Muslim Mission. He eventually decentralized the group, asking local communities to take responsibility for their own mosques. It was largely a successful revolution, and the followers of W. D. Mohammed, who died in 2008, can still be found throughout the country. ${ }^{83}$

While most of the local congregations associated with W. D. Mohammed's new Nation of Islam remained loyal to him, not all Nation of Islam leaders and followers were happy with the change in 1975. By 1978, Minister Louis Farrakhan, who initially expressed his loyalty to W. D. Mohammed, broke away to form his own version of the Nation of Islam. Though he did not inherit the mosques associated with W. D. Mohammed, he successfully allied with some former leaders in the Nation of Islam, recruited new members and disaffected Muslims in W. D. Mohammed's group, and built his own movement based on interpretations of Elijah Muhammad's teachings. Minister Farrakhan adopted and then adapted the mathematic, scientific, and technological aspects of Elijah Muhammad's thought, especially the extensive teachings about the Mother Plane that Elijah Muhammad revealed in the early 1970s. Numerology and Masonic elements also came to play a significant role in Minister Farrakhan's speeches; one fine example of this is his speech at the 1995 Million Man March on the National Mall in Washington, D.C. ${ }^{84}$ The Mother Plane, which was redubbed the Mother Ship and the Mother Wheel, was perhaps more important to his religious experience and authority than it had been to Elijah Muhammad. In 1985, Farrakhan said, he was in Tepotzlan, Mexico, when he had a vision of visiting the Mother Ship. He was transported to the UFO by a beam of light—something that Elijah Muhammad had not experienced-and he 
was eventually able to speak with the Messenger there and gain invaluable prophetic insights into his leadership of the new Nation of Islam and its role in the Reagan era. ${ }^{85}$ According to one scholar, who has offered fulllength treatment of the incident, it was the most formative religious encounter in Minister Farrakhan's life. ${ }^{86}$

Rather than presenting an amalgamated, static view of the scientific and technological teachings associated with the history of various branches of the Nation of Islam, this article has analyzed the history of Elijah Muhammad's Nation of Islam within the historical contexts of the 1950 s, 1960s, and 1970s. It has suggested how various elements of middle to late twentieth-century science and technology-from the dreadful crematoriums of Auschwitz and changing postwar view of UFOs as flying saucers to eugenics programs and research on healthy diet-informed the Nation of Islam's religious thought and practice. Instead of dismissing Elijah Muhammad's sometimes correct, sometimes wildly incorrect appropriations of mathematics and science as entertaining but ultimately silly cultic oddities, I have sought to explain how Elijah Muhammad and many of his followers believed that their practice of Islam was rational and scientific, how math and science reflected the real, untold story of black people's origins and destiny, and how technology has been abused in the past, but through the vehicle of the Mother Plane, would usher in a black utopia. Like other extraterrestrial and UFO religions, the Nation of Islam largely rejected spiritual and metaphysical explanations that some unseen force was the pulling the strings of the universe; instead, it offered a materialistic explanation of how people had been created, why bad things happened to them, what they could do to improve their situation, and how everything would turn our perfect in the end. Elijah Muhammad's Nation of Islam was thoroughly invested in the language of science and technology, offering what its followers believed was a path to justice and a better life.

\section{ENDNOTES}

1 A notable exception is Michael Lieb, Children of Ezekiel: Aliens, UFOs, the Crisis of Race, and the Advent of the End Time (Durham, N.C.: Duke University Press, 1998). My study builds on Lieb's analysis of science and technology in the movement by emphasizing religious practice as well as religious thought and by doing so from the viewpoint of rank-and-file members as well as leaders.

${ }^{2}$ This body of literature includes dozens of books and hundreds of articles. On the Nation of Islam as a form of black nationalism, see E. U. Essien-Udom, Black Nationalism: The Search for an Identity (Chicago: University of Chicago Press, 1962) and C. Eric Lincoln, The Black Muslims in America (Boston: Beacon, 1961). For organization histories, see Mattias Gardell, In the Name of Elijah Muhammad: Louis Farrakhan and the Final Call (Durham: Duke University Press, 1996) and Clifton 
E. Marsh, The Lost-Found Nation of Islam (Lanham: Scarecrow Press, 2000). On its religious elements, see Edward E. Curtis IV, Black Muslim Religion in the Nation of Islam, 1960-1975 (Chapel Hill: University of North Carolina Press, 2006). On women in the Nation of Islam, see Dawn-Marie Gibson and Jamillah Karim, Women of the Nation: Between Black Protest and Sunni Islam (New York: New York University Press, 2014).

${ }^{3}$ For a study that situates the Nation of Islam within the larger history of Muslim American organizations, see Kambiz GhaneaBassiri, A History of Islam in America: From the New World to the New World Order (New York: Cambridge University Press, 2010).

${ }^{4}$ See Manning Marable, Malcolm X: A Life of Reinvention (New York: Viking, 2011).

5 Martin Luther King, Jr., "Letter from the Birmingham Jail," in Black Writers in America, ed. Richard Barksdale and Kenneth Kinnamon (Englewood Cliffs, N.J.: Prentice Hall, 1972), 867-68.

6 Sean McCloud, Making the American Religious Fringe: Exotics, Subversives, and Journalists, 1955-1993 (Chapel Hill: University of North Carolina Press, 2004), $55-94$.

7 Benjamin E. Zeller, Prophets and Protons: New Religious Movements and Science in Late Twentieth-Century America (New York: New York University Press, 2010), 118, and compare Brenda Denzler, The Lure of the Edge: Scientific Passions, Religious Beliefs, and the Pursuit of UFOs (Berkeley: University of California Press, 2001); James R. Lewis, ed., The Gods Have Landed: New Religions from Other Worlds (Albany: State University of New York Press, 1995); and Christopher H. Partridge, UFO Religions (London: Routledge, 2003).

8 Zeller, Prophets and Protons, 118-119.

9 For more on the "traditional appeals" of new religious movements, see James R. Lewis, Legitimating New Religions (New Brunswick, N.J.: Rutgers University Press, 2003), 13-14.

10 Paul Brian Thomas, "Revisionism in ET-Inspired Religions," Nova Religio 14, no. 2 (2010): 61-83.

11 My sources include the publications and speeches of Nation of Islam leaders, especially Elijah Muhammad; catechisms used at Nation of Islam meetings and study sessions; and the poetry and commentary of rank-and-file Nation of Islam members in Muhammad Speaks newspaper, which remains the single best contemporaneous record of members' activities.

12 Warner X Berry, "War Vet Credits Messenger Muhammad for Restoring His Peace of Mind," Muhammad Speaks, 6 April 1966, 25.

13 Dr. Leo X, "On the Scientific Significance of Teachings of the Messenger of Allah," Muhammad Speaks, 28 May 1965. See also Brother Warren X Payne, "Awareness of Self, Allah Are Islam's Gift to the Black Race," Muhammad Speaks, 11 April 1969, and Walter 3X Epps, "The Atom and Islam: The Messenger Is Our Nucleus,” Muhammad Speaks, 5 November 1971, 15.

14 George X Tucker, “Black Honduran Finds New Life in Messenger's Teachings," Muhammad Speaks, 19 August 1966, 25.

15 Sylane X, Muhammad Speaks, April 1962, as quoted in Curtis, Black Muslim Religion, 15. Pace Sylane X's creedal formulation here, most Islamic traditions do 
acknowledge angels, the resurrection of bodies, and life after death as foundational doctrines.

${ }^{16}$ Elijah Muhammad, Message to the Blackman in America (Newport News, VA: United Brothers Communication Systems, 1992 [1965]), 1-3.

17 Muhammad, Message to the Blackman, 3.

18 Michael Barkun, A Culture of Conspiracy: Apocalyptic Visions in Contemporary America (Berkeley: University of California Press, 2009), 26-27.

19 Thomas, "Revisionism in ET-Inspired Religions," 66.

${ }^{20}$ Muhammad, Message to the Blackman, 8, 16-17.

${ }^{21}$ My versions of the catechisms come from the F.B.I.'s declassified 1955 internal monograph about the Nation of Islam. See "Nation of Islam Part 1 of 3," FBI Records: The Vault, http://vault.fbi.gov/Nation\%20of\%20Islam/ Nation\%20of\%20Islam\%20Part\%201\%20of\%203/view, last accessed March 10, 2015. The FBI conducted surveillance on many important African American organizations in the twentieth century due to the widespread belief among Bureau personnel that any public organizing conducted by African Americans was a potential danger to the (white supremacist) status quo. See, for example, Robert A. Hill, editor, The FBI's RACON: Racial Conditions in the United States during World War II (Boston: Northeastern University Press, 1995). 22 “Actual Facts," 83-84. There was a distinction made sometimes between "Facts" and "Actual Facts," though in practice this distinction could be blurred. 23 "Student Enrollment (10 Questions)," in "Nation of Islam Part 1 of 3," 73. This geographical information likely reflected not only the scientific impulse in the Nation of Islam but also resonated with Elijah Muhammad's teaching that Muslims should acquire "land of their own" for the purpose of achieving political and economic independence from whites. Though the Nation of Islam was for the most part an urban movement, the yeoman ideal of independent, landholding, self-determined black farmers continued to hold meaning long after most African Americans had left the rural South. The Messenger himself eventually purchased several farms from which he could source the healthy foods that he asked believers to eat and supply grocery stores associated with his network of believers across the United States. See Bayyinah Sharrieff, "The Miracle of Muhammad: Development of Cattle Industry," Muhammad Speaks, 13 November 1970, 18, and Muhammad Speaks, 2 August 1968, 19.

24 "Allah and His Messenger," Muhammad Speaks, 1 January 1965, 1.

25 "Actual Facts," 84, in "Nation of Islam Part 1 of 3."

${ }^{26}$ Muhammad, Message to the Blackman, 31.

27 Elijah Muhammad, The Supreme Wisdom: Solution to the So-Called Negroes' Problem (Newport News, VA: National Newport News and Commentator, n.d. [1957]), 12-13.

28 Thomas, "Revisions in ET-Inspired Religions," 67.

29 Muhammad, Message to the Blackman, 108-109.

30 Muhammad, Message to the Blackman, 108.

31 Catherine L. Albanese, Republic of Mind and Spirit: A Cultural History of American Metaphysical Religion (New Haven: Yale University Press, 2008), 6, and 
see J. Stillson Judah, The History and Philosophy of the Metaphysical Movements in America (Philadelphia: Westminster, 1967).

32 Albanese, Republic of Mind and Spirit, 133.

33 For a genealogy of African American esoteric groups and ideas during this period, see Jacob Dorman, "Black Orientalism and Black Gods of the Metropolis," in The New Black Gods: Arthur Huff Fauset and the Study of African American Religions, ed. Edward E. Curtis IV and Danielle Brune Sigler (Bloomington: Indiana University Press, 2009), 116-142.

34 "Student Enrollment (10 Questions)," 72-73.

35 See further Richard Brent Turner, Islam in the African-American Experience, 2d ed. (Bloomington: Indiana University Press, 2003).

36 “14 Questions," p. 78.

37 Muhammad, Message to the Blackman, 31.

38 Elijah Muhammad banned chemical hair treatments, which he saw as unnatural and unhealthy. But many women in the Nation of Islam did use hot combs to straighten their "untamed" hair. Men often cut their hair short. These styles of coiffure were in keeping, said Sister Kathleen X of Mosque No. 25 in Newark, New Jersey, with the respectable, natural, and modest hairstyles of modern African people: "Examine pictures of the Original people of contemporary Africa." she wrote. "Of course you do not find plastered-down, greasy coifs. But, you cannot say these hairstyles are towering fly-catchers, either." Sister Kathleen X, "Shun the Afro!" Muhammad Speaks, 12 September 1969, 21.

39 Lincoln, Black Muslims in America, 72.

40 Muhammad, Message to the Blackman, 110-114.

41 Muhammad, Message to the Blackman, 112, 114-115.

42 See further Stefan Kühl, "The Cooperation of German Racial Hygeniests and American Eugenecists before and after 1933," in The Holocaust and History: The Known, the Unknown, the Disputed, and the Reexamined, ed. Michael Berenbaum and Abraham Peck (Bloomington: Indiana University Press, 1998), 134-152, and compare Stefan Kühl, The Nazi Connection: Eugenics, American Racism, and German National Socialism (New York: Oxford University Press, 1994).

43 Dorothy E. Roberts, Killing the Black Body: Race, Reproduction, and the Meaning of Liberty (New York: Pantheon, 1997), 90-95.

44 Muhammad, Message to the Blackman, 64.

45 Curtis, Black Muslim Religion, 95-130.

46 See Muhammad, Message to the Blackman, 31, 82-84, 110-22, and 230-32, and Muhammad, Supreme Wisdom, 11, 15, 29, 31, 33, 36, and 38.

47 "Actual Facts," 85. For the significance of 1914 to the Jehovah's Witnesses, see Zoe Knox, "Writing Witness History: The Historiography of the Jehovah's Witnesses and the Watch Tower Bible and Tract Society of Pennsylvania," Journal of Religious History 35, no. 2 (June 2011): 167.

48 Muhammad, Message to the Blackman, 16-17.

49 Accounts of the early years of Elijah Muhammad's leadership of the Nation of Islam can be found in Claude Andrew Clegg III, The Life and Times of Elijah Muhammad (Chapel Hill: University of North Carolina Press, 2014 [1997]), and 
Karl Evanzz, The Messenger: The Rise and Fall of Elijah Muhammad (New York: Vintage, 2001).

${ }^{50}$ On differing views of the movement's radical politics, compare Hans Baer and Merrill Singer, African American Religion: Varieties of Protest and Accommodation (Knoxville: University of Tennessee Press, 2002), 113-151, especially 148, and Curtis, Black Muslim Religion, 127-130.

51 Muhammad, Supreme Wisdom, 15.

${ }^{52}$ Edward E. Curtis IV, "Islamizing the Black Body: Ritual and Power in Elijah Muhammad's Nation of Islam," Religion and American Culture 12, no. 2 (2002): 167-196.

53 Essien-Udom, Black Nationalism, 205-6; Elijah Muhammad, How to Eat to Live, Book No. 2 (1972; repr. Newport News Va.: National Newport News and Commentator, n.d.), 65-66, 78, 87-93, 108, 113, 141; and "The Devil's Diet for the Righteous," Muhammad Speaks, 26 May 26 1967, 14.

54 Muhammad, Message to the Blackman, 17; see also Muhammad, Supreme Wisdom, 11.

55 "Actual Facts," 83.

56 Sister Anne 3X, "Girl Counts Her Blessings since Joining With Islam," Muhammad Speaks, 20 December 1963, 7; Allen 3X, "How Messenger Muhammad's Dietary Rules Saved My Life," Muhammad Speaks, 9 April 1971, 28; Bayyinah Sharrieff, "Good Health with Muhammad's Program," Muhammad Speaks, 23 April 1971, 15.

57 Samuel 25X, "Recent Scientific Research Confirms Messenger's 40-Year Dietary Teachings," Muhammad Speaks, 7 May 1971, 22, and see further C. M. McKay, "Effect of Restricted Feeding and Chronic Diseases in Rats and Dogs," American Journal of Public Health 37, no. 5 (1947): 521-28.

58 Sister Kris X, "The Holy City," Muhammad Speaks, 27 March 1964, 11.

59 Lieb, Children of Ezekiel, 146-147.

60 Elijah Muhammad, The Supreme Wisdom, 14. The idea of a fiery apocalypse, which was part of African American spirituals and folklore, was also picked up by James Baldwin in his 1963 book, The Fire Next Time (New York: Dial Press, 1963).

61 Compare Stephen C. Finley, "The Meaning of Mother in Louis Farrakhan's 'Mother Wheel': Race, Gender, and Sexuality in the Cosmology of the Nation of Islam's UFO," Journal of the American Academy of Religion 80, no. 2 (2012): 434-65. ${ }^{62}$ Muhammad, Message to the Blackman, 240-242.

63 "Radio Listeners in Panic, Taking War Drama as Fact," New York Times, 31 October 1938, 1; Hadley Cantril, The Invasion from Mars: A Study in the Psychology of Panic (Princeton: Princeton University Press, 1940), 55, 58-60, 71,133, 180.

${ }^{64}$ Sidney Shalett, "What You Can Believe about Flying Saucers," Saturday Evening Post 221, no. 44 (30 April 1949): 20-21,136-139.

65 Benson Saler, Charles A. Ziegler, and Charles B. Moore, UFO Crash at Roswell: The Genesis of a Modern Myth (Washington, D.C.: Smithsonian Institution Press, 1997), 6, 10-14, 146-147.

${ }^{66}$ William Sims Bainbridge and Rodney Stark, "Cult Formation: Three Compatible Models," Sociological Analysis 40 (1979): 283-95, and compare Leon Festinger, Henry W. Riecken, and Stanley Schachter, When Prophecy Fails: 
A Social and Psychological Study of a Modern Group that Predicted the End of the World (London: Pinter and Martin, 2008 [1956]).

67 Elijah Muhammad, The Fall of America (1973, repr. Newport News, Va.: National Newport News and Commentator, n.d.).

68 See Paul Boyer, When Time Shall Be No More: Prophecy Belief in Modern American Culture (Cambridge, Mass.: Harvard University Press, 1992) and compare Matthew Avery Sutton, American Apocalypse: A History of Modern Evangelicalism (Cambridge, Mass.: Harvard University Press, 2014).

69 Muhammad, Fall of America, 241-242.

70 Elijah Muhammad generally used the Muhammad Ali translation of the Qur'an. See The Holy Quran, trans. Muhammad Ali (Lahore Ahmadiyya Movement, 2002), http://www.muslim.org/english-quran/quran.htm.

71 Muhammad, Fall of America, 237.

72 Muhammad, Fall of America, 238-239.

73 Muhammad, Fall of America, 239.

74 Muhammad Speaks, 11 February 11 1972, 4.

75 Muhammad, Supreme Wisdom, 23. Emphasis added.

76 Lieb, Children of Ezekiel, 144.

77 Muhammad, Supreme Wisdom, 25.

78 Lieb, Children of Ezekiel, 12-13.

79 Lieb, Children of Ezekiel, 14-17.

80 “Hon. Elijah Muhammad, Theology of Time Series, August 6, 1972," https:/ / www.youtube.com $/$ watch?v=zgALNPUyWF0\&feature=youtu.be, last accessed March 10, 2015.

81 Lieb, Children of Ezekiel, 171-172.

${ }^{82}$ Lieb, Children of Ezekiel, 176.

83 The story of the transition is told, among other places, in Marsh, From Black Muslims to Muslims, and Turner, Islam in the African-American Experience.

84 Louis Farrakhan, "Speech at the Million Man March," October 16, 1995. https://www.youtube.com/watch?v=U8UB-shmJfQ, last accessed March 10, 2015 .

85 Gardell, In the Name of Elijah Muhammad, 131-133.

${ }^{86}$ Finley, "The Meaning of Mother in Louis Farrakhan's 'Mother Wheel'," 434. 